\title{
Diversity of Insect Pollinators in Gozamin District of Amhara Region, Ethiopia
}

\author{
Manaye Misganaw ${ }^{1, ~ *, ~ G i r m a ~ M e n g e s h a ~}{ }^{2}$, Tesfaye Awas ${ }^{1}$ \\ ${ }^{1}$ Ethiopian Biodiversity Institute, Addis Ababa, Ethiopia \\ ${ }^{2}$ Wondo Genet College of Forestry and Natural Resources, Shashemene, Ethiopia
}

Email address:

manaye9@gmail.com (M. Misganaw), tesfayeawas@gmail.com (T. Awas), gutgirma@gmail.com (G. Mengesha)

${ }^{*}$ Corresponding author

\section{To cite this article:}

Manaye Misganaw, Girma Mengesha, Tesfaye Awas. Diversity of Insect Pollinators in Gozamin District of Amhara Region, Ethiopia. American Journal of BioScience. Vol. 8, No. 5, 2020, pp. 123-131. doi: 10.11648/j.ajbio.20200805.11

Received: August 12, 2020; Accepted: August 25, 2020; Published: September 14, 2020

\begin{abstract}
Pollination is one of a valuable ecosystem services in the maintenance of biodiversity and ensures the survival of plant species. Therefore, Insect pollinators' diversity and their role in the ecosystem are not sufficiently recorded; thus, conducting assessment of their diversity and roles helps to recognize the economic and ecological value of insect pollination, and potential impacts of the loss of insect pollinators. Therefore, the overall aim of this study was to assess and identify insect pollinators' diversity and frequently visited plant species in cropland and natural habitat of the study area. Transect sampling and direct field observation was used to collect data. The abundance of insect pollinators from the three study sites were sampled systematically using two transects one along the Shrubland and the other on farmland habitat. A total of 60 transect sample plots 30 in the farmland and 30 in the Shrubland habitats were observed in the study areas. A total of 34 insect pollinator species were identified. The most frequently recorded insect pollinator was Apis mellifera in Shrubland (60.4\%) and farmland (67.3\%). Insect diversity of the Shrubland was higher $\left(H^{\prime}=1.72\right)$ than farmland $\left(H^{\prime}=1.514\right)$. Similarly, evenness was higher in the Shrubland $\left(\mathrm{J}^{\prime}=0.5485\right)$ as compared to farmland $\left(\mathrm{J}^{\prime}=0.4974\right)$ which is somehow even distribution in both habitats. To understand the most visited plants by insect pollinators 40 wild plants and 4 crop species were identified. Among the sampled plants Crassocephalum macropappurn was the most frequently visited plant by different insect pollinators while Guizotia abyssinica was the most frequently visited among the sampled crops. The study has shown occurrence of diverse insect pollinators and plant species visited by insect pollinators as function of ecosystem services in the area.
\end{abstract}

Keywords: ApisMellifera, Ecosystem Service, Frequently Visited Plants, Insect Diversity, Pollinators Conservation

\section{Introduction}

Biological diversity is important for ecosystem functioning and services, not only as the basis for processes in nature, but also as a prerequisite for the improvement and sustainability of human wellbeing [1]. Pollination is one of a valuable ecosystem services in the maintenance of biodiversity and ensures the survival of plant species [2]. It improves the yield of most crop species and contributes to one-third of global crop production [3].

Pollination is the transfer of pollen from a flower's male organ to a flower's female organ [4]. Pollinators are insects, including honey bees, as well as birds and some mammalsthat transfer pollen from one flower to another.
They provide ecosystem service that result in the outcrossing and sexual reproduction of many plants [5]. Moreover, they benefit humans by increasing food production, foodsecurity which in turn improving theirlivelihoods and play a great role in conserving biodiversity in agricultural and natural ecosystems [5]. Consequently, pollinators are considered ecologically keystones; because, a major threat to pollinators is destruction of habitat and loss of forage whichis subjected to the spread of invasive alien species [6].

Flowering plant species $(87.5 \%)$ require an animal pollinator to reproduce [7]. Thus, in the absence of pollinators, many native plants can't produce seeds and ensure continuity of the plant species to next generation. These seeds and fruits the plants bear are important sources 
of food for birds and many mammal species, including humans. However, as a result of self-incompatibility in many plant species (over 300 species of 70 families), active and functional pollen grains failed to effect fertilization on selfpollination lead and lacked seed set [8].

As [9] noted, greater than three quarters of the leading types of global food crops were rely on animal pollination for yield and/or quality. However, pollinators have been getting lost globallyresulting in reduction of pollination services [10]. For instance, according to [11] $\$ 302$ billion reduction in the value of production across all sectors and regions representing $0.39 \%$ decrease from the 2004 baseline was reported. This was reported to happen mainly due to human induced impacts such as habitat destruction, land use change and use of chemicals, climate change, and invasive species $[12,13]$. These have led to a reduction of both the number of individuals and species of native insect pollinators of crops and wild plants [14].

In agro-ecosystems, abundances and distribution of pollinator species which could be dependent on habitat factors are affecting yields of agricultural products and other agroecosystem functions in many ways [15]. Thus, the habitat composition and configuration along landscape have large impact on local farmers' food production. Service providing organisms, such as pollinators and natural enemies of crop pests, often disperse from natural and semi-natural habitats into farmland, increase yields and they are important to keep nature around farmland $[16,17]$. Hence, assessing, identifying, documenting and managing pollinators' diversity in Ethiopia could have significant effect on the conservation and improvement of plant diversities in the country.

Recording insect pollinators' diversity and its role in the ecosystem is indispensable for determining the status of pollinators and developing appropriate management plans for the conservation of threatened insect pollinator species in Ethiopia. Thus, conducting pollinators' diversity assessment helps to recognize the economic and ecological value of pollinating animals, and potential impacts of the loss of pollinators' particularly insect pollinator-related ecosystem services and functions [5]. Furthermore, the acquired information would be important for the farming communities, policy-makers and scaled up to other such places. Therefore, the objective of this study is to assess and identify insect pollinators diversity and frequently visited plant species in cropland and natural habitat (Shrubland) of the area of Gozamin district.

\section{Materials and Methods}

\subsection{The Study Area}

The study district (Gozamin) is one of the 166 districts of Amhara National Regional State and one of the 20 districts of East Gojjam Zone. It has 25 rural kebeles, and one sub- city center. The district was bordered by Sinan district to the North, Machacle and Debre Eliyas districts to the West, Abay River Gorge to the South and Basoliben and Anedede district to the East. It occurs at $299 \mathrm{~km}$ from the West of Addis Ababa and $269 \mathrm{~km}$ from Bahir Dar, and located at $10^{\circ} 36^{\prime} 18^{\prime \prime} \mathrm{N}$ and $37^{\circ} 55^{\prime} 02$ " E with an altitudinal range of 1000-3200 masl. [18] (Figure 1). The mean annual temperature records of the study area were in between $11.04^{\circ} \mathrm{C}$ and $25^{\circ} \mathrm{C}$, whereas the mean annual rain fall distribution was in between 1448 $1888 \mathrm{~mm}$ [19]. The district has a total population of 153,295 of which 75,390 and 77,905 are male and female respectively where a few $2.82 \%$ of the populations live in urban and $97.18 \%$ in rural areas [19]. Ethnically, the majority of the population of the district is 'Amhara' and 'Amharic' is the main language used. Most of the populations (99.97\%) are Orthodox, followed by Muslim (0.02\%) and the rest are other religion followers [19]. Sedentary rain feed agricultural activities are practiced; and economy of the people are primarily based on mixed cereal crop growth such as Teff, Sorghum, Maize, Barley, Wheat, Pulses, Oil crops, Potato, Vegetables and Fruits.

Due to high anthropogenic effect in the study area, most of the original indigenous forest areas have been converted into other land use types, though remnant plants around holy places, inaccessible areas, and left for shade trees still persist [18]. Some of the remnant common indigenous plant species of the forest include Juneperus procera, Hagenia abyssinica, Podocarpus falcatus, Acacia abysinica, Cordia africana, Ficus sycomorus, Erythrina brucei, Calpurnia aurea, Prunus africana, Carissa spinarum, Rosa abyssinica, Dombeya torrid and Maytenus arbutifolia.

\subsection{Sampling \& Method of Data Collection}

The study district was selected purposively based on the wild plant and crop diversity and relative altitude difference of the study sites (kebeles). Based on the information from agriculture office Enerata, Yebona-Erjena, and Chimit kebeles were selected randomly after grouping each kebeles of the district in a relative altitude (dega, weynadega and kola) respectively.

Sampling of insect pollinators'observation, identification and recording and plant specimens from each study site were carried out within $10^{\text {th }}-30^{\text {th }}$ October 2015. Shrubland and Farmland habitats were selected in order to assess insect pollinators' diversity and plant flowers preferred by them. The abundance of insect pollinators in each study sites (Chimit, Enerata and Yebona -Erjena) were sampled using two transects. 'Transects' were the walk or path followed in the assessment to collect a sample of insect pollinators and plant specimens during the study. However, 'transect sample plot' was the plot area in which insect pollinators flower visitation, researcher observation and specimen collection were carried out. Each transect sample plot had $2 * 2$ meter observation area which was designed by string [20]. Thus, one transects sampling conducted along the Shrubland and the other on farmland habitat.

A total of 60 sample plots were selected for observation of visitation in the whole study area. Twenty sample plots were observed in each of the sampled kebeles, ten in the Shrubland and ten in the farmland habitats. The distance between 
consecutive transect sample plot in the Shrubland was determined according to [21]. There was a difficulty to measure transects on two lines of the Shrubland habitat; therefore, single transect walk was performed. Each consecutive transect sample plots of the Shrubland habitat was sampled and observed within 50 to $60 \mathrm{~m}$ distance which was measured by walk (70 to 90 steps) approximately. Therefore, along the Shrubland habitat 1.5 to $1.8 \mathrm{~km}$ transect path was assessed in the whole study area, and 0.5 to $0.6 \mathrm{~km}$ of transect line walk was conducted in every study site. In each transects insect pollinators visiting plant and crop flowers and the plant species were recorded carefully. Moreover, Plants of Shrubland habitat in the transect sample plot, of which insect pollinators visit its flowers were identified in the field with the help of botanist. However, plants difficult to identify in the transect sample plot were specimens collected and pressed after giving accession number.

Farmland sampling was done with in $1 \mathrm{~km}$ radius from any edge of the Shrubland habitat. This was due to scattered cultivation of the targeted crops in farmland habitat. Thus, the observer moved in a zigzag path to get insect pollinators from crop flowers. Observations were carried out under good weather conditions when insect pollinators are active, foraging, low wind, Sunny and warm unclouded days. In addition, plant and insect pollinator interactions were observed from 10:00 to12:00 a. m. and between 1:00-4:00 p. m. [22, 21]. Each sample plot was determined to 30 minutes chance of observation. While collection, recording of insect pollinators and change in observer position was in every seven to eight minutes. This was to ensure access to insect pollinator from different directions and to avoid bias due to shading.

The known insect pollinator species in each transect sample plot which visits plant and crop flowers were identified and recorded while unknown insect pollinators were captured for further identification using internet catalogue, taxonomist and identification books. Plant specimens' identification was conducted after the death of plants with the help of flora books of Ethiopia. However, plants which were difficult to identify be subjected to the national herbarium of Addis Ababa University for better identification. After the plant identification, mounting and leveling of passport data on the specimens and storing in Herbarium were conducted.

\subsection{Data Analysis}

The collected insect pollinators' diversity was calculated using Paleontological Statistics Software Package (PAST) andShannon wiener index $\left(\mathrm{H}^{\prime}\right)$. $\mathrm{H}^{\prime}$ defined as: $H^{\prime}=-\sum$ pi $\ln$ $p i$, with pi as the proportion of individuals found in the $i^{\text {th }}$ species [23]. Species accumulation curves were used to illustrate the rate of new species in the study area. Moreover, measures of dissimilarity coefficient were conducted to assure insect pollinators' diversity distribution of the study sites.

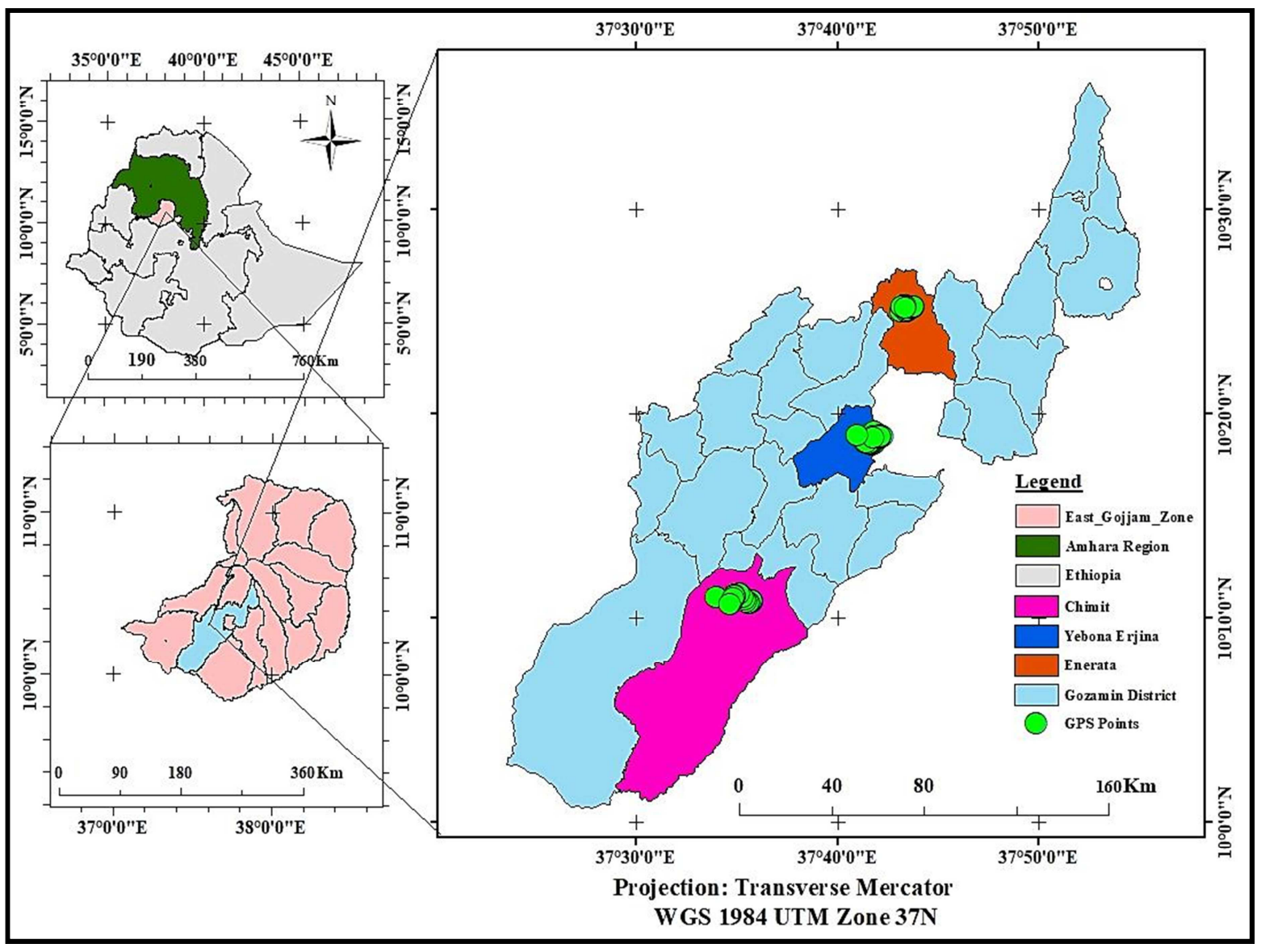

Figure 1. Map of the study area showing the sample sites. 


\section{Result and Discussion}

\subsection{Estimating the Species Richness}

Observations and samplings of insect pollinator species visit at the first sample plot of the farmland habitat were significant effects $\left(\chi^{2}=32.000,4 \mathrm{df}, \mathrm{P}<0.01\right)$. While, insect pollinators visit at the first sample plot of Shrubland habitats were not significant effects $\left(\chi^{2}=4.545,1 \mathrm{df}, \mathrm{P}>0.01\right)$. However, after taking a series of samples, insect pollinator visits were significant at farmland $\left(\chi^{2}=8567.044,20 \mathrm{df}, \mathrm{P}<\right.$ $0.001)$ and the Shrubland $\left(\chi^{2}=5793.011,23 \mathrm{df}, \mathrm{P}<0.001\right)$. Significance of the beginning observation and the whole sample shows insect visits and time of sampling were correctly matched.

Species richness in farmland and Shrubland habitats were estimated in Figure A and B. Species accumulation curves on Shrubland habitats indicates that unlikely to find new insect pollinator species. The probability of getting new species was reduced and no more species obtained. However, the farmland accumulation curve is still undulating indicates further research is necessary to determine optimum diversity of insect pollinators. As [24] described the number of species found increases as more samples are added, and when the line starts to bend (the inflection point) this suggests one is nearing the true total number of species in the habitat being sampled.
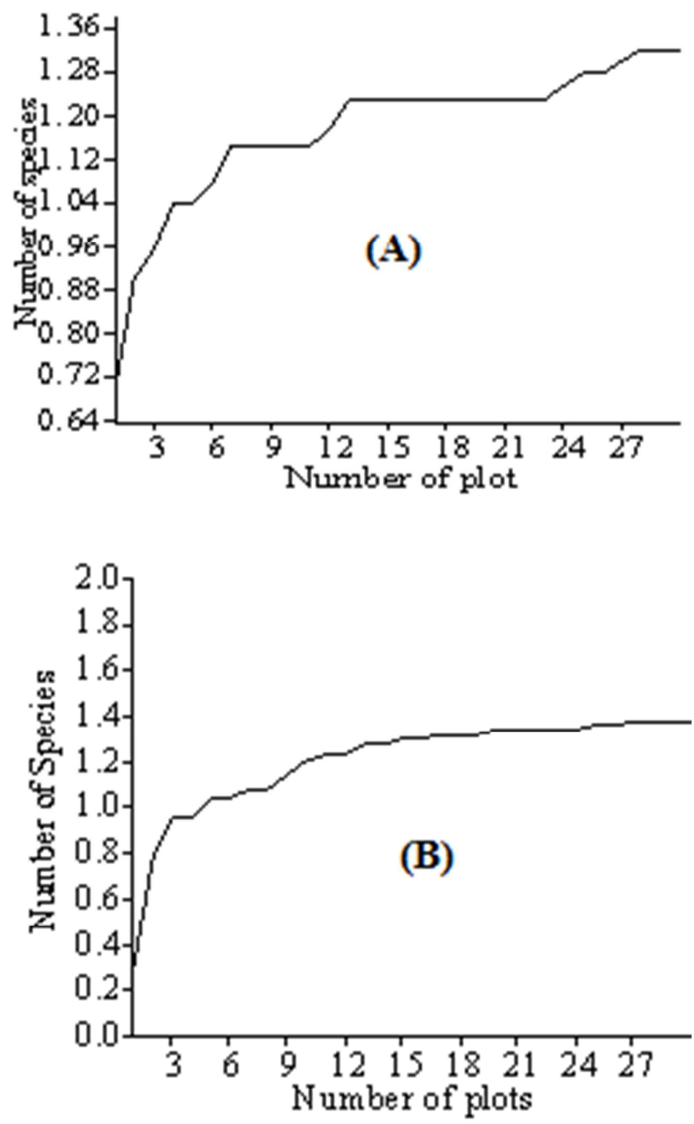

Figure 2. Species accumulation Curve of farmland (A) and Shrubland (B) habitats showing richness.

\subsection{Insect Pollinators Visit Recorded in Both Habitats}

A total of 34 insect pollinator species belong to 26 families and 5 orders were recorded in the study (Table: 1). Out of these, 23 species of insect pollinators were recorded in Shrubland habitat and 21 species of insect pollinators' recorded in farmland habitats with total counts of 712 and 983 visits respectively (Table: 2 ).

Table 1. Insect Pollinators Identified in both Habitats.

\begin{tabular}{|c|c|c|c|}
\hline NO & Order & Family & Species name \\
\hline 1 & Coleoptera & Meloidae & Actenodia curtula \\
\hline 2 & Coleoptera & Curculionidae & Apion occidentale \\
\hline 3 & Coleoptera & Paralauca & Besouro paralauca dives \\
\hline 4 & Coleoptera & Cerambaycidae & Ceroplesis thunbergi \\
\hline 5 & Coleoptera & Cantharidae & Chauliognathus lugubris \\
\hline 6 & Coleoptera & Scarabaidae & Diplognatha gagates \\
\hline 7 & Coleoptera & Coccinellidae & Epilachna borealis \\
\hline 8 & Coleoptera & Scarabaidae & Pachnoda sinuata \\
\hline 9 & Coleoptera & Scarabaidae & Pachnoda stehelini \\
\hline 10 & Coleoptera & Scarabaidae & Rutelinae sp. \\
\hline 11 & Diptera & Tipulidae & Nephrotoma cornicina \\
\hline 12 & Diptera & Syrphidae & Sphaerophoria scripta \\
\hline 13 & Hemiptera & Blissidae & Blissus sp. \\
\hline 14 & Hemiptera & Miridae & Campyloneura virgula \\
\hline 15 & Hemiptera & Pentatomidae & Eurydema oleracea \\
\hline 16 & Hemiptera & Pentatomidae & Euschistus sp. \\
\hline 17 & Hemiptera & Coreidae & Leptoglossum gonagra \\
\hline 18 & Hymenoptera & Apidae & Apis mellifera \\
\hline 19 & Hymenoptera & Argidae & Arge sp. \\
\hline 20 & Hymenoptera & Pompilidae & Cyphononyx optimus \\
\hline 21 & Hymenoptera & Eumenidae & Delta emarginatum \\
\hline 22 & Hymenoptera & Ichneumonidae & Ichneumon wasps \\
\hline 23 & Hymenoptera & Megachilidae & Parafidelia major \\
\hline 24 & Hymenoptera & Vespidae & Polistes sp. \\
\hline 25 & Hymenoptera & Apidae & Xylocopa caffra \\
\hline 26 & Hymenoptera & Apidae & Xylocopa sp. \\
\hline 27 & Lepidoptera & pieridae & Coliascroceus \\
\hline 28 & Lepidoptera & Nymphalidae & Danaus chrysippus \\
\hline 29 & Lepidoptera & pieridae & Eurema hecabe \\
\hline 30 & Lepidoptera & Sphingidae & Macroglossum trochilus \\
\hline 31 & Lepidoptera & Papilionidae & Mocker swallowtail \\
\hline 32 & Lepidoptera & Notodontidae & Phalerasp. \\
\hline 33 & Lepidoptera & Nymphalidae & Polygonia C-album \\
\hline 34 & Lepidoptera & Nymphalidae & Vanessa abyssinica \\
\hline
\end{tabular}

Most of the species (13) were recorded in Shrubland habitats, 11 species in the farmland and the remaining 10 species were recorded in both habitats. As [25] noted number of species of insect pollinators varied across the two major habitats even if similar species were present. Because, Pollinator diversity varies between habitats, both in species richness and number of individuals recorded. Apis mellifera were the highest count $430(60.3 \%)$ in Shrubland and 662 $(67.3 \%)$ in farmland and highest abundance mean (143.33+ $6.13)$ in Shrubland and $(220.67+10.30)$ in farmland (Table: 2) this shows honeybees are assumed to be the most important insect pollinator of plant and crop flowers. 
Honeybee is the most important commercial pollinating insect, and its importance is increasing because of reduction in the number of wild honeybees and wild pollinators [26]. Apis mellifera were the most frequently recorded insect pollinator in the Shrubland habitat followed by Rutelinae species and Colias croceus (Table: 2) which is not similar to [27] wild bees provide more visitation than managed Apis mellifera. However, Campyloneura virgule and Eurydema oleracea are the least insect pollinators observed during the transect assessment of Shrubland habitat.

Table 2. Insect pollinators recorded in Shrubland and Farmland habitats along the sampled kebeles.

\begin{tabular}{|c|c|c|c|c|c|c|c|}
\hline \multirow{2}{*}{ Pollinator Species names } & \multicolumn{7}{|c|}{ Shrubland Habitat } \\
\hline & Chimit & Enerata & Yebona & Total count (TC) & Abundance mean & Mean + SEM & \%Total count \\
\hline Actenodia curtula & 32 & 0 & 0 & 32 & 10.67 & $10.67+6.13$ & 4.5 \\
\hline Apion occidentale & 11 & 3 & 0 & 14 & 4.67 & $4.67+6.13$ & 2 \\
\hline Apis mellifera & 120 & 168 & 142 & 430 & 143.33 & $143.33+6.13$ & 60.3 \\
\hline Blissus sp. & 0 & 0 & 3 & 3 & 1 & $1.00+6.13$ & 0.4 \\
\hline Ceroplesis thunbergi & 6 & 0 & 0 & 6 & 2 & $2.00+6.13$ & 0.8 \\
\hline Colias croceus & 5 & 6 & 4 & 15 & 5 & $5.00+6.13$ & 2.1 \\
\hline Cyphononyx optimus & 9 & 0 & 0 & 9 & 3 & $3.00+6.13$ & 1.3 \\
\hline Danaus chrysippus & 2 & 0 & 0 & 2 & 0.67 & $0.67+6.13$ & 0.3 \\
\hline Delta emarginatum & 0 & 0 & 9 & 9 & 3 & $3.00+6.13$ & 1.3 \\
\hline Eurema hecabe & 7 & 0 & 0 & 7 & 2.33 & $2.33+6.13$ & 1 \\
\hline Euschistus sp. & 2 & 0 & 0 & 2 & 0.67 & $0.67+6.13$ & 0.3 \\
\hline Ichneumon wasps & 0 & 5 & 0 & 5 & 1.67 & $1.67+6.13$ & 0.7 \\
\hline Leptoglossus gonagra & 5 & 3 & 0 & 8 & 2.67 & $2.67+6.13$ & 1.1 \\
\hline Macroglossum trochilus & 5 & 4 & 0 & 9 & 3 & $3.00+6.13$ & 1.3 \\
\hline Mocker swallowtail & 0 & 4 & 4 & 8 & 2.67 & $2.67+6.13$ & 1.1 \\
\hline Pachnoda stehelini & 9 & 8 & 36 & 53 & 17.67 & $17.67+6.13$ & 7.4 \\
\hline Parafidelia major & 4 & 0 & 0 & 4 & 1.33 & $1.33+6.13$ & 0.6 \\
\hline Polygonia c-album & 2 & 9 & 0 & 11 & 3.67 & $3.67+6.13$ & 1.5 \\
\hline Rutelinae species & 4 & 10 & 0 & 14 & 4.67 & $4.67+6.13$ & 2 \\
\hline Sphaerophoria scripta & 0 & 5 & 0 & 5 & 1.67 & $1.67+6.13$ & 0.7 \\
\hline Xylocopa caffra & 6 & 0 & 2 & 8 & 2.67 & $2.67+6.13$ & 1.1 \\
\hline Xylocopa sp. & 40 & 0 & 14 & 54 & 18 & $18.0+6.13$ & 7.6 \\
\hline Total $\left(\sum\right)$ & 269 & 229 & 214 & 712 & & & 100 \\
\hline
\end{tabular}

Table 2. Continue.

\begin{tabular}{|c|c|c|c|c|c|c|c|}
\hline \multirow{2}{*}{ Pollinator Species names } & \multicolumn{7}{|c|}{ Farmland Habitat } \\
\hline & Chimit & Enerata & Yebona & Total count (TC) & Abundance mean & Mean + SEM & $\%$ Total count \\
\hline Apis mellifera & 246 & 228 & 188 & 662 & 220.67 & $220.67+10.30$ & 67.3 \\
\hline Arge sp. & - & - & 6 & 6 & 2 & $2.00+10.30$ & 0.6 \\
\hline Besouro paralauca dives & - & - & 15 & 15 & 5 & $5.00+10.30$ & 1.5 \\
\hline Campyloneura virgula & 4 & - & - & 4 & 1.33 & $1.33+10.30$ & 0.4 \\
\hline Colias croceus & 5 & 20 & 16 & 41 & 13.67 & $13.67+10.30$ & 4.2 \\
\hline Danaus chrysippus & 7 & 9 & 3 & 19 & 6.33 & $6.33+10.30$ & 2 \\
\hline Diplognatha gagates & 15 & - & - & 15 & 5 & $5.00+10.30$ & 1.5 \\
\hline Epilachna borealis & - & - & 17 & 17 & 5.67 & $5.67+10.30$ & 1.7 \\
\hline Eurema hecabe & 8 & - & - & 8 & 2.67 & $2.67+10.30$ & 0.8 \\
\hline Eurydema oleracea & 4 & - & - & 4 & 1.33 & $1.33+10.30$ & 0.4 \\
\hline Macroglossum trochilus & 11 & 9 & 6 & 26 & 8.67 & $8.67+10.30$ & 2.6 \\
\hline Mocker swallowtail & 6 & 4 & 8 & 18 & 6 & $6.00+10.30$ & 1.9 \\
\hline Nephrotoma cornicina & - & 5 & - & 5 & 1.67 & $1.67+10.30$ & 0.5 \\
\hline Pachnoda sinuata & 20 & 4 & - & 24 & 8 & $8.00+10.30$ & 2.4 \\
\hline Parafidelia major & 6 & - & - & 6 & 2 & $2.00+10.30$ & 0.6 \\
\hline Phalera sp. & - & 5 & - & 5 & 1.67 & $1.67+10.30$ & 0.5 \\
\hline Polistes sp. & - & - & 6 & 6 & 2 & $2.00+10.30$ & 0.6 \\
\hline Polygonia c-album & 4 & 5 & 9 & 18 & 6 & $6.00+10.30$ & 1.9 \\
\hline Rutelinae species & 23 & 23 & 13 & 59 & 19.67 & $19.67+10.30$ & 6 \\
\hline Sphaerophoria scripta & - & 7 & - & 7 & 2.33 & $2.33+10.30$ & 0.7 \\
\hline Vanessa abyssinica & 18 & - & - & 18 & 6 & $6.00+10.30$ & 1.9 \\
\hline Total $\left(\sum\right)$ & 377 & 319 & 287 & 983 & & & 100 \\
\hline
\end{tabular}

N. B: SEM (standard Error of Mean) Diversity of Insect pollinators in both habitats. 
Table 3. Comparison of diversity results in different indices of Shrubland and Cropland habitats.

\begin{tabular}{|c|c|c|c|c|c|c|c|c|c|c|c|c|}
\hline \multirow[b]{2}{*}{ Index Name } & \multicolumn{6}{|c|}{ Shrubland habitat } & \multicolumn{6}{|c|}{ Cropland habitat } \\
\hline & Chimit & Enerata & $\begin{array}{l}\text { Yebona- } \\
\text { Erjena }\end{array}$ & Combined & $\begin{array}{l}\text { Upper } \\
\text { boundary }\end{array}$ & $\begin{array}{l}\text { Lower } \\
\text { boundary }\end{array}$ & Chimit & Enerata & $\begin{array}{l}\text { Yebona- } \\
\text { Erjena }\end{array}$ & Combined & $\begin{array}{l}\text { Upper } \\
\text { boundary }\end{array}$ & $\begin{array}{l}\text { Lower } \\
\text { boundary }\end{array}$ \\
\hline Taxa (S) & 17 & 12 & 8 & 23 & 21 & 23 & 14 & 11 & 11 & 21 & 20 & 21 \\
\hline Individuals & 269 & 229 & 214 & 712 & 712 & 712 & 377 & 319 & 287 & 983 & 983 & 983 \\
\hline $\mathrm{D}=\sum \mathrm{Pi}^{2}$ & 0.2425 & 0.5458 & 0.4756 & 0.3807 & 0.34 & 0.4226 & 0.4388 & 0.5231 & 0.4437 & 0.4626 & 0.426 & 0.5 \\
\hline $1-\mathrm{D}$ & 0.7575 & 0.4542 & 0.5244 & 0.6193 & 0.5773 & 0.6591 & 0.5612 & 0.4769 & 0.5563 & 0.5374 & 0.4995 & 0.5738 \\
\hline $\mathrm{H}^{\prime}$ & 1.976 & 1.196 & 1.136 & 1.72 & 1.58 & 1.823 & 1.471 & 1.194 & 1.399 & 1.514 & 1.401 & 1.607 \\
\hline Brillouin & 1.868 & 1.113 & 1.076 & 1.659 & 1.522 & 1.762 & 1.403 & 1.133 & 1.329 & 1.471 & 1.359 & 1.562 \\
\hline Menhinick & 1.037 & 0.793 & 0.5469 & 0.862 & 0.787 & 0.862 & 0.721 & 0.6159 & 0.6493 & 0.6698 & 0.6379 & 0.6698 \\
\hline Margalef & 2.86 & 2.024 & 1.305 & 3.35 & 3.045 & 3.35 & 2.191 & 1.735 & 1.767 & 2.903 & 2.757 & 2.903 \\
\hline $\mathrm{J}^{\prime}=\mathrm{H}^{\prime} / \mathrm{H}^{\prime} \max$ & 0.6975 & 0.4815 & 0.5463 & 0.5485 & 0.5073 & 0.583 & 0.5575 & 0.4978 & 0.5832 & 0.4974 & 0.4602 & 0.5277 \\
\hline Fisher alpha & 4.033 & 2.694 & 1.64 & 4.545 & 4.06 & 4.545 & 2.864 & 2.209 & 2.269 & 3.772 & 3.555 & 3.772 \\
\hline Berger-parker & 0.4461 & 0.7336 & 0.6636 & 0.6039 & 0.566 & 0.639 & 0.6525 & 0.7147 & 0.6551 & 0.6734 & 0.6439 & 0.7009 \\
\hline
\end{tabular}

N. B. Simpson index $(D)=\left(\sum \mathrm{Pi}^{2}\right)$, Simpson $=(1-D)$, Shannon Diversity $\left(\mathrm{H}^{\prime}\right)$, Equitability $\left(\mathrm{J}^{\prime}\right)=\left(\mathrm{H}^{\prime} / \mathrm{H}^{\prime} \mathrm{max}\right)$

Insect pollinators diversity across the Shrubland habitat were highest in Chimit $\left(H^{\prime}=1.976\right)$, with evenness value (H'/H'max) of (0.6975) (Table 3). The combined Shannon insect pollinators diversity $\left(\mathrm{H}^{\prime}=1.72\right)$ was moderate diversity with evenness value of (0.5485) (Table 3). Of the sites in the farmland Enerata was the smallest species diversity $\left(H^{\prime}=1.194\right)$, while Chimit was relatively highest number of species record $\left(\mathrm{H}^{\prime}=1.471\right)$ (Table 3). However, Equitability of Chimit (0.5575) and Yebona-Erjena (0.5832) showing insect pollinators were relatively distributed evenly; and Enerata $\left(\mathrm{J}^{\prime}=0.4978\right)$ was low evenness (Table 3$)$. Moreover, the combined diversity $\left(H^{\prime}=1.514\right)$ of farmland habitat was less than that of Shrubland habitat (1.726) (Table 3). Shannon-wiener and Simpson indices indicated that diversity of insect pollinator was from medium to low condition in both habitats even if Apis mellifera visit frequently. As [28] reported crop area was not evenly distributed with a dominance of some species and the forest area was evenly distributed with only a negligible dominance.

\subsection{Analysis of Similarity Index}

Coefficients of dissimilarity in both habitats showed insect pollinators were dissimilar, as Jaccard and Sorensen coefficient approach to zero. However, the Sorensen similarity index in combined data (farmland with Shrubland) showed more than half of insect pollinators obtained during the assessment were similar (Table: 4).

Table 4. Result of Jaccard and Sorensen dissimilarity coefficient compared in both habitats.

\begin{tabular}{llllllll}
\hline \multirow{2}{*}{$\begin{array}{l}\text { Dissimilarity } \\
\text { coefficient }\end{array}$} & \multicolumn{2}{l}{ Shrubland site compared } & & \multicolumn{3}{l}{ Farmland site compared } \\
\cline { 2 - 8 } & $\begin{array}{l}\text { Chimit with } \\
\text { Enerata }\end{array}$ & $\begin{array}{l}\text { Chimit with } \\
\text { Yebo }\end{array}$ & $\begin{array}{l}\text { Enerata with } \\
\text { Yebo }\end{array}$ & $\begin{array}{l}\text { Chimit with } \\
\text { Enerata }\end{array}$ & $\begin{array}{l}\text { Chimit with } \\
\text { Yebo }\end{array}$ & $\begin{array}{l}\text { Enerata } \\
\text { Yebo }\end{array}$ & $\begin{array}{l}\text { Fith } \\
\text { Shrubland }\end{array}$ \\
\hline Jaccard & 0.216 & 0.148 & 0.182 & 0.242 & 0.219 & 0.241 \\
Sorensen & 0.356 & 0.258 & 0.308 & 0.39 & 0.359 & 0.389 \\
\hline
\end{tabular}

\subsection{Plant Species and Insect Pollinators}

A total of 40 flowering plant species from 18 plant families were recorded in the natural habitat during the study (Table: 5). The most visited plant families were Asteraceae (12 spp.), followed by Fabaceae ( 7 spp.) and Acanthaceae ( 5 spp.). Most of the insect pollinators' visited plant flowers from Asteraceae (27.9\%), Acantaceae (14.5\%) and Fabaceae (13.1\%).

Table 5. Plants Visited by Insect Pollinatorsin the Natural Habitat.

\begin{tabular}{|c|c|c|c|c|}
\hline NO & Species Name & Family & Local name & No of pollinators \\
\hline 1 & Acanthus pubescens & Acanthaceae & kosheshla & 22 \\
\hline 2 & Achyranthes aspera & Amaranthaceae & T'elenge & 24 \\
\hline 3 & Aeschynomene abyssinica & Fabaceae & - & 34 \\
\hline 4 & Barleria ventricosa & Acanthaceae & - & 5 \\
\hline 5 & Bidens pachyloma & Asteraceae & Adeye & 35 \\
\hline 6 & Buddleja polystachya & Buddlejaceae & Anfare & 14 \\
\hline 7 & Caesalpinia decapetala & Fabaceae & - & 20 \\
\hline 8 & Carissa spinarum & Apocynaceae & Agam & 56 \\
\hline 9 & Clematis hirsuta & Ranunculaceae & - & 4 \\
\hline 10 & Crassocephalum macropappurn & Asteraceae & Monto & 46 \\
\hline 11 & Equinops sp. & Asteraceae & - & 17 \\
\hline 12 & Glycine wightii & Fabaceae & - & 3 \\
\hline 13 & Gnidia glauca & Thymelaeaceae & Awora & 13 \\
\hline 14 & Gouania longispicata & Rhamnaceae & - & 24 \\
\hline 15 & Guizotia scabra & Asteraceae & Meche & 32 \\
\hline
\end{tabular}




\begin{tabular}{lllll}
\hline NO & Species Name & Family & Local name & No of pollinators \\
\hline 16 & Helichrysum sp. & Asteraceae & - & 11 \\
17 & Helinus mystacinus & Rhamnaceae & - & 2 \\
18 & Hibiscus macranthus & Malvaceae & - & 8 \\
19 & Hygrophilia auriculata & Acanthaceae & Ameykela & 38 \\
20 & Hypericum quartinianvm & Hypericaceae & Ameja & 22 \\
21 & Hypoestes forskaolii & Acanthaceae & - & 5 \\
22 & Ipomoea sp. & Covolvulaceae & - & 25 \\
23 & Justicia schimperiana & Acanthaceae & Sensel & 33 \\
24 & Lantana trifolia & Verbenaceae & Yeeregnakolo & 7 \\
25 & Maytenus arbutifolia & Celastraceae & Atate & 5 \\
26 & Mikaniopsis clematoides & Asteraceae & - & 5 \\
27 & Pavoni aurens & Malvaceae & Nacha & 16 \\
28 & Phaseolus sp. & Fabaceae & - & 5 \\
29 & Rosa abyssinica & Rosaceae & Qega & 52 \\
30 & Rumex nepalensis & Polygonaceae & Qtele-rejim & 6 \\
31 & Rumex nervosus & Polygonaceae & Im'bwach'o & 16 \\
32 & Senecio ochrocarpus & Asteraceae & - & 9 \\
33 & Senna didnobotrya & Fabaceae & Gemaie & 22 \\
34 & Senna septemtrionalis & Fabaceae & - & 5 \\
35 & Senna singueana & Fabaceae & Gufa & 4 \\
36 & Solanum incanum & Solanaceae & Zercho & 16 \\
37 & Sonchus bipontini & Asteraceae & 6 \\
38 & Verbascum sinaiticum & Scrophulariaceae & Yeahyajero & 7 \\
39 & Vernonia auriculifera & Asteraceae & Gengerita & 7 \\
40 & Vernonia sp. & Asteraceae & - & 31 \\
\hline
\end{tabular}

The maximum plant recorded per plot was 5 species while the minimum was single species. Crassocephalum macropappurn was the most visited plant species by different insect pollinators (Apis mellifera, Rutelinae sp., Polygonia calbum, Apion occidentale, Chauliognathus lugubris, and Colias croceus). The plant Hygrophilia auriculata and Rosa abyssinica were visited by 5 insect species each; Guizotia scabra, Solanum incanum and, Carissa spinarum were visited by 4 insect species each; Pavonia urens, Gouania longispicata, Bidens pachyloma, Caesalpinia decapetala and Achyranthes aspera were visited by 3 insect species each; and Rumex nepalensis, Justicia schimperiana, Acanthus pubescens, Ipomoea sp., Hypericum quartinianvm, Senna didnobotrya, Rumex nervosus and Buddleja polystachya were visited by 2 insect species each. However, the rest plant species (21) were visited by a single insect species. Asteraceae family plant flowers attracted insect pollinators reflect, flower appearance in this family have a better attracting aroma, brightened color, and preferable resource (nectar and pollen) than those plant families observed in this study. Crassocephalum macropappurn was visited by many insect pollinators indicates the plant have the richest source of nectar and pollen. Honeybees collect pollen and nectar from Crassocephalum macropappurn frequently and the long flowering period is very helpful for strengthening bee colonies and it was a good source of honey [29]. Low flowering plant record with in a plot indicate how much the diversity of plants were disturbed, and flowers visited by single species of insect pollinators indicate insect pollinators prefer the resource obtained from plants which is pollen and nectar.

\subsection{Crop Species and Insect Pollinators}

Totally four cultivated crop types were assessed in this study (Table: 6). Niger seed (Guizotia abyssinica) was highly visited (893 times or $90.84 \%$ ) by insect pollinators and Rape seed (Brassica napus) was the least visited (1.42\%). Order Hymenoptera was the most frequent crop pollinator species $(69.2 \%)$ and Hemiptera was the least pollinator species $(0.8 \%)$. The most frequent crop visitors were Apis mellifera (67.34\%). However, Eurydema oleracea and Campyloneura virgule were recorded as the least visitors $(0.4 \%)$. Honeybees visit crop flower more reflects these species are the main insect pollinators of agricultural landscape. As [30] reported honeybees are the most widely used insect pollinator in agricultural systems, as they are easily managed. Honeybees and other insect pollinators have significant effect on Niger seed yield, so that keep their colonies neighboring to flowers of Niger seed in order to optimize pollination efficiency and enhance productivity [31].

Table 6. Crop species visited by insect pollinators.

\begin{tabular}{|c|c|c|c|c|c|c|}
\hline \multirow[t]{2}{*}{ Crop species } & \multirow[t]{2}{*}{ Scientific name } & \multicolumn{3}{|c|}{ No of pollinators recorded in each study site } & \multicolumn{2}{|r|}{$\%$ Total } \\
\hline & & Chimit & Enerata & Yebo & Total & \\
\hline Niger seed & Guizotia abyssinica & 363 & 308 & 222 & 893 & 90.84 \\
\hline Rapeseed & Brassica napus & 14 & 0 & 0 & 14 & 1.42 \\
\hline linseed & Linum usitatissimum & 0 & 11 & 11 & 22 & 2.43 \\
\hline Grass pea & Lathyrus sativus & 0 & 0 & 54 & 54 & 5.49 \\
\hline
\end{tabular}




\section{Conclusion and Recommendations}

The result of the study revealed that there were a total of 34 insect pollinators in both the Shrubland and farmland habitats of the study area. The finding also showed that diversity of insect pollinators in the study area was from mid-to low and Apis mellifera was the most numerous and frequent insect pollinator among other insects identified in the study area. Findings from the plant indicated that Asteraceae was the most frequently visited plant family by insect pollinators in the area. Therefore, this has shown occurrence of diverse insect pollinators and plant species visited by insect pollinators' as function of ecosystem services in the area. Finally a need of further research to determine insect pollinators' diversity in different season to detect trends, distributions, yearly abundances and population fluctuation are important. Conducting research of identification on crop pest from insect pollinators' and awareness creation on the use of insects to farmers which are pollinators or not.

\section{Acknowledgements}

I am greatly thanks to Ethiopian Biodiversity Institute, for the financial support. My thanks also went to the staff of Gozamin district Agricultural Office, especially Mr. Esuyawukal Tirunehe and the study kebeles extension agents. Dr. Tesfu Fukensa cooperation on insects' identification was also likely appreciated.

\section{References}

[1] Callicott JB, Crowder LB, Mumford K (1999). Current Normative Concepts in Conservation. Conservation Biology 13: 22-35.

[2] Kluser S, Peduzzi P (2007). Global Pollinator Decline: A Literature Review, UNEP/GRID Europe, UNEP.

[3] Klatt B. K, Holzschuh A, Westphal C, Clough Y, Smit I, Pawelzik E, Tscharntke T (2014). Bee pollination improves crop quality, shelf life and commercial value. Proc. R. Soc. B 281: 20132440. http://dx.doi.org/10.1098/rspb.2013.2440.

[4] Roubik DW (1995). Pollination of Cultivated Plants in the Tropics. Rome, Italy: Food and Agriculture Org., UN.

[5] African Pollinator Initiative (API) (2006). Pollinators and pollination: A resource book for policy and practice. ISBN: 186849-310-5. pp. 1-52.

[6] Peterson W, John SR, Ellsworth D, Colopy M (2015). Pollinators and Rights-of-Way. pp. 36-39.

[7] Ollerton J, Winfree R, Tarrant S (2011). How many flowering plants are pollinated by animals? Oikos, 120: 321-326.

[8] Patil HS, Duhoon SS (2006). Self-Incompatibility, Male Sterility and Pollination Mechanism in Niger \{Guizotia abyssinica (L. F.) CASS.\}. A review. All India Coordinated Research Project on Niger, Zonal Agricultural Research Station, India: 113-121.
[9] Intergovernmental Science Policy platform on Biodiversity and Ecosystem Services (IPBES) (2016). Summary for Policymakers of the Assessment Report on Pollinators, Pollination and Food Production. Pp 10.

[10] Winfree R, Ramiro A, Diego P, Vazquez, Gretchen L, Marcelo A, Aizen (2009). A meta-analysis of bees' response to anthropogenic disturbance. University of Californi, Berkeley, California 94720-3114 USA. Ecology, 90 (8): 2068-2076.

[11] Bauer DM, Wing IS, (2011). The Macroeconomic Cost of Catastrophic Pollinator Declines, Department of Geography and Environment, Boston University. USA. pp.13.

[12] Kearns CA, Inouye DW, Waser NM, (1998). Endangered Mutualism: The Conservation of Plant-pollinator Interaction. Annu. Rev. Ecol. 29: 83-112.

[13] Goulson DG, Lye C, Darvill B (2008). Decline and conservation of bumble bees. Annual Review of Entomology 53: 191-208.

[14] Vanbergen AJ, Insect Pollinators Initiative (IPI) (2013). Threats to an ecosystem service: pressures on pollinators. Frontiers in Ecology and the Environment, doi: $10.1890 / 120126$

[15] Ulrika S (2016). The impact of forest on pest damage, pollinators and pollination services in an Ethiopian agricultural landscape. Stockholm University, Sweden, ISBN 978-91-7649-354-0.

[16] Bianchi F, Booij CJ, Tscharntke T (2006). Sustainable pest regulation in agricultural landscapes: a review on landscape composition, biodiversity and natural pest control. Proceedings of the Royal Society B-Biological Sciences, 273: 1715-1727.

[17] Macfadyen S, Hopkinson J, Parry H, Neave MJ, Bianchi F, Zalucki MP (2015). Early-season movement dynamics of phytophagous pest and natural enemies across a native vegetation-crop ecotone. Agriculture Ecosystems and Environment, 200: 110-118.

[18] Haimanot R, Zemede A, Ensermu K (2015). Contribution of Traditional Farmers for Medicinal Plant Conservation on the Farming Site in Gozamin District, Amhara Region, Ethiopia. International Journal of Life Sciences 4: 24-35.

[19] Gozamin District Finance and Economic Development office (GDFED) (2015). The second five year Growth and transformation plan. Integrated Budget Planning and development case team (unpublished). Pp.4-5.

[20] Hennig EI, (2011). Plant Diversity Effects on Plant-Pollinator Interactions in Urban and Agricultural Settings. University Duisburg-Essen. pp. 10-80.

[21] Ward K. D, Cariveau E, May M, Roswell M, Vaughan N, Williams R, Winfree R, Isaacs, Gill K. (2014). Streamlined Bee Monitoring Protocol for Assessing Pollinator Habitat. Portland, OR: The Xerces Society for invertebrate Conservation. pp. 16.

[22] Food and Agriculture Organization (FAO) (2011). Protocol To Detect And Assess Pollination Deficits In Crops: A Handbook For Its use. Pollination service for Sustainable Agriculture. Field manual, Rome Italy. pp 20-50.

[23] Magurran AE (2004). Measuring Biological Diversity. Blackwell Publishing. pp. 106-110. 
[24] Adams J (2009). Species Richness Patterns in the Diversity of Life. Springer-Praxis Books in Environmental Sciences Subject Advisory Editor, ISBN 978-3-540-74277-7. pp. 1-20.

[25] Stojnić SM, Andrić A, Józan Z, Vujić A (2012). Pollinator diversity (Hymenoptera and Diptera) in semi-natural habitatsin Serbia during summer. University of Novi Sad, Serbia 2 H-7453 Mernye, Hungary.

[26] James ET (2004). Backyard Beekeeping. Alabama Cooperative Extension System. ISBN 0-9722580-6-X. pp. 25.

[27] Winfree R, Neal M, William, Hannah G, John S, Ascher, Kremen C (2008). Wild bee pollinators provide the majority of crop visitation across land-use gradients in New Jersey and Pennsylvania, USA. Princeton University, Princeton, NJ 08544, USA. Journal of Applied Ecology, 45: 793-802.
[28] Zahoor MK., Suhail A, Iqbal J, Zulfaqar Z, Anwar M (2003). Biodiversity of Noctuidae (Lepidoptera) in Agro-Forest Area of Faisalabad, University of Agriculture, Government of Punjab, Pakistan Int. J. Agri. Biol. 5: 560-563.

[29] Fichtl R, Admasu A (1994). Honeybee Flora of Ethiopia. Margraf, Verlag, Weikersheim, Germany. ISBN 3-8236-12344. pp. 45.

[30] Park M, Bryan D, John L, David B, Mace V, Jolie D, Edwin R, Arthur A (2012). Wild Pollinators of Eastern Apple Orchards and How to Conserve Them. Cornell University, The Xerces Society.

[31] Haftom G, Alemayehu T (2014). Effect of honey bee (Apis mellifera) pollination on seed yield and yield parameters of Guizotia abyssinica (L. F), Apiculture and sericulture case team, Mekelle Agricultural Research center. 9: 3687-3691. 